\title{
XXIVème Congrès de la SALF 6 - 8 décembre 2007, COLMAR
}

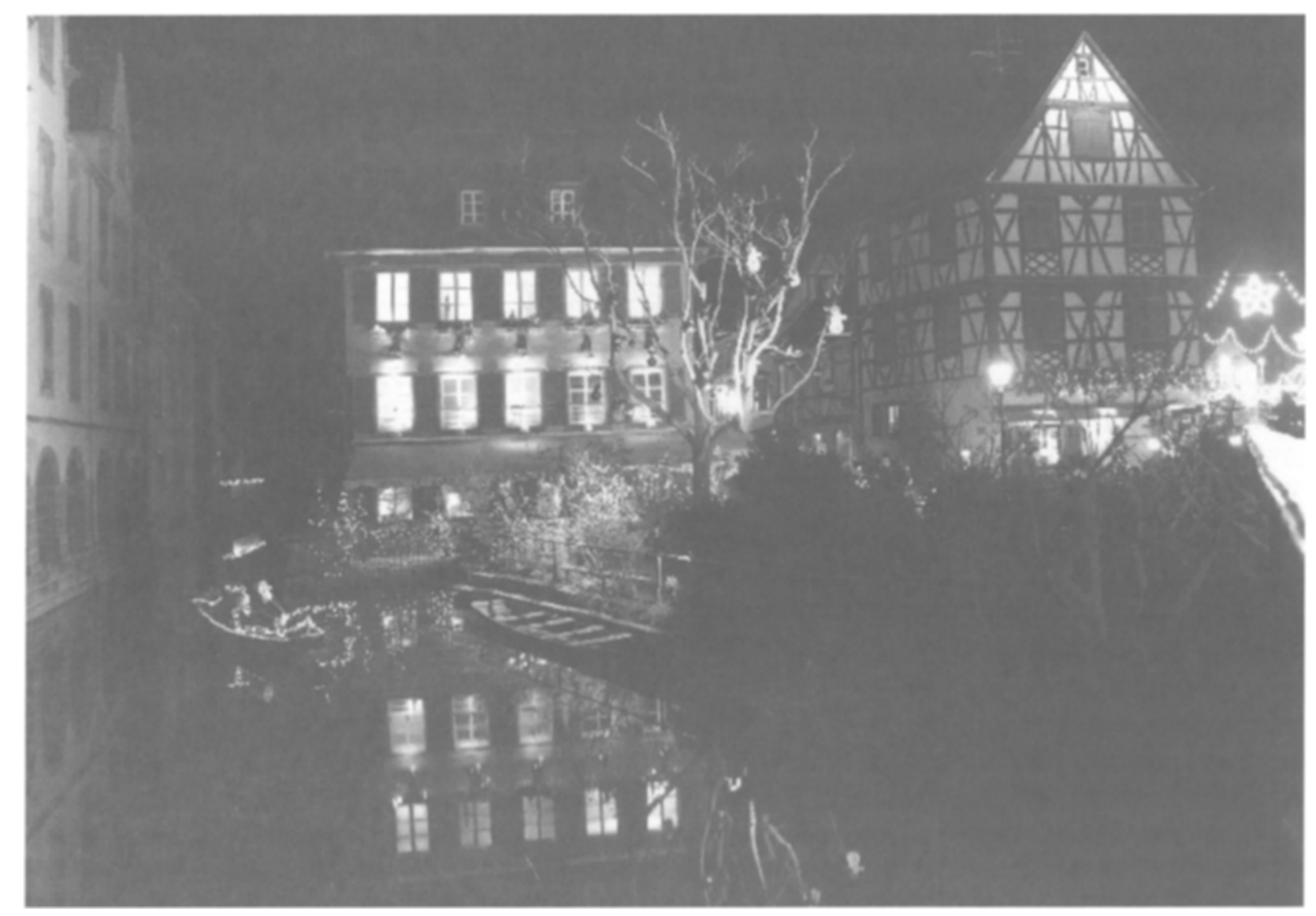

